C. 2 .

11. Ложные слухи // Московская газета. 1914. № 337.

12. Германская ложь // Пермская земская неделя. 1914. № 38. С. 11.

13. Политика и поэтика: русская литература в историко-культурном контексте Первой мировой войны. Публикации, исследования и материалы. М.: ИМЛИ РАН, 2014. 880 с.

14. От штаба Верховного Главнокомандующего // Новое время. 1914. № 13798. С. 1.

15. От штаба Верховного Главнокомандующего // Новое время. 1914. № 13784. С. 1.

16. Война России с Германией и Австро-Венгрией // Пермская земская неделя. 1914. № 34. С. 3.

17. Победоносное движение // Утро в Харькове. 1914. № 2426. С. 2. C. 3 .

18. Кузьма Крючков // Русское слово. 1914. № 197.

19. Война России с Германией и Австро-Венгрией // Пермская земская неделя. 1914. № 35. С. 3-4.

20. Около войны // Мариупольская жизнь. 1914. № 2349. C. 3 .

21. В городах Восточной Пруссии // Вестник войны. 1914. № 1. С. 2.

22. Хлеб-соль немцев русским войскам // Московская копейка. 1914. № 47. С. 2.

23. От штаба Верховного Главнокомандующего // Новое время. 1914. № 13797. С. 1.

24. Русский театр // Речь. 1914. № 214 (2883). С. 2.

\title{
THE EAST PRUSSIAN OPERATION (1914) COVERAGE IN RUSSIAN NEWSPAPERS
}

(C) 2020

Pimenov Oleg Vladimirovich, postgraduate student of National and Universal History, Archeology Department Volgograd State University (Volgograd, Russian Federation)

Abstract. The paper deals with the issues of the East Prussian operation (1914) coverage in Russian Newspapers On the basis of various newspapers the author analyzes the coverage of the Russian and German troops actions in East Prussia in August-September 1914. The author also reveals fundamental themes of Russian newspapers when covering the East Prussian operation. The paper is based on various newspapers of the Russian Empire. The following Russian newspapers were analyzed: «Vestnik voyny», «Donetskaya zhizn», «Mariupolskaya zhizn», «Moskovskaya kopeyka», «Novoye vremya», «Permskaya zemskaya nedelya», «Rech», «Russkoe slovo», «Utro v Kharkiv». The study was focused on Petrograd and Moscow newspapers, as well as regional newspapers that, among other things, reprinted material from other publications on their pages. The study showed that Russian newspapers, when covering the East Prussian operation, were characterized by creating a positive impression among readers, focusing on the successes of the tsarist army. Readers were introduced to victories, both at the level of large military formations and at the level of small military units. The defeats of the Russian troops were presented by the newspapers not as a tragedy, but as a short-term failure, followed by quick victories.

Keywords: agitation; battle of Gumbinnen; battle of Tannenberg; newspapers; the East Prussian operation; information war; the battle of Mazur; «Moskovskaya kopeyka»; «Novoye vremya»; image of the enemy; World War I; «Permskaya zemskaya nedelya»; propaganda; «Russkoe slovo».

$* * *$

УДК 93/94

DOI 10.24411/2309-4370-2020-11210

Статья поступила в редакцию 14.01.2020

\section{КОНФЛИКТЫ КРЕСТЬЯН В МАРТЕ-ОКТЯБРЕ 1917 Г. (НА МАТЕРИАЛАХ ВЛАДИМИРСКОЙ ГУБЕРНИИ)}

(C) 2020

Птицына Галина Михайловна, ассистент кафедры истории России

Владимирский государственньй университет

имени Александра Григорьевича и Николая Григорьевича Столетовых (2. Владимир, Российская Федерация)

Аннотация. В данной статье представлен анализ социального поведения крестьян Владимирской губернии в марте - октябре 1917 г., а именно их конфликтов, и выделены основные направления конфронтации. Дана характеристика степени разработанности проблемы как советской, так и современной исторической наукой. 
Птицына Г.М.

Конфликты крестьян в марте-октябре 1917 г. (на материалах Владимирской губернии) Исторические науки и археология

Объясняется ограниченность использования данных статистики по выбранному региону и определяется методологическая основа исследования. Автор рассматривает конфликты крестьян не только со стороны статистики, но и с позиции единичных сюжетов, которые лучше раскрывают повседневные поведенческие практики. В работе подробно характеризуются и группируются столкновения интересов крестьян с окружающей социальной действительностью. В заключение делается вывод о несостоятельности тезиса советской историографии о том, что основными врагами для крестьян были помещики, кулаки и «буржуазное» Временное правительство. В результате анализа источников выявлено, что община в марте - октябре 1917 г., решая свои насущные вопросы продовольствия и землепользования, оказалась против всех. Её конфликты проходили сразу на нескольких осях: «город - деревня», «община - частные владельцы», «община - община» и внутриобщинные споры. Возникали также конфликты с государством, но они были отнюдь не политическими.

Ключевые слова: русское крестьянство; Русская революция 1917 г.; Владимирская губерния; Временное правительство; крестьянская община; общинная революция; крестьянское движение; социальное поведение; конфликты; провинциальное общество; революционная власть; историческая антропология; история повседневности.

Современные исследователи всё чаще подчеркивают решающую роль крестьян и их сознания в революции 1917 г. И дело не только в подавляющей численности крестьян, но также и в том, что они оказались тем народообразующим элементом, из рядов которого вышли многие слои населения, включая пролетариев [1, с. 307-308].

Цель данной статьи: анализ социального поведения крестьян Владимирской губернии в марте - октябре 1917 г., а именно их конфликтов, и определение основных направлений конфронтации. Территориальные рамки исследования ограничены Владимирской губернией в силу того, что местному крестьянству в революционных событиях 1917 года не было посвящено специальных работ. Более того, губерния является типичной для нечерноземного центра, что позволит дополнить общую картину региона.

Важно, что рассматривать конфликты крестьян предполагается не только со стороны сухой статистики, но и с позиции единичных сюжетов, которые лучше раскрывают повседневные поведенческие практики. Поэтому методологически исследование отчасти опирается на историю повседневности, которая, изучая человеческую обыденность в ее социокультурном и политическом контекстах, исследует в том числе «многообразие индивидуальных реакций на политические события» [2, с. 7, 12].

В советской историографии бесспорное первенство в революционных процессах 1917 г. признавалось за рабочими, а поведение крестьян и их социальные взаимодействия изучались в рамках ленинской концепции аграрной революции. Историки акцентировали внимание на классовой борьбе крестьян с помещиками и кулаками, на созревании предпосылок социалистической революции и переходе крестьян к осени 1917 г. на позиции большевиков [3-5]. Одним из осмелившихся отрицать революционность крестьянства был С.В. Тютюкин [6, с. 80-85].

Важнейшей вехой изучения крестьянского поведения в 1917 г. стало появление термина «общинная революция», авторами которого были В.М. Бухарев и Д.И. Люкшин. Согласно этой концепции, у крестьян в марте - октябре 1917 г. не было четких политических намерений: община рьяно отстаивала традиционное, уравнительное землепользование, а власть, сделавшая ставку на дальнейшее развитие капиталистических отношений, противоречила ей [7, с. 157].

Идею «общинной революции» дополнили последующие исследования, поставившие под сомнение политический характер крестьянских выступлений [8, с. $150 ; 9$, с. 22-38]. А историк В.П. Булдаков при- шел к выводу, что желание «черного передела» поставило крестьян в состояние конфликта со всем окружающим миром - государством, помещиками, хуторянами, отрубниками, городом и другими общинами [10, с. 51].

Термин «социальное поведение» применительно к крестьянам в 1917 г. одной из первых затронула О.С. Поршнева. Она определила его как осознанные и неосознанные реакции на воздействия социальной среды, включая приспособление к ней, и рассматривала, прежде всего, влияние на эти процессы менталитета $[11$, с. 12$]$. Эта же проблема ставилась и в ряде других диссертационных исследований - все они обладают региональной спецификой, вводя в научный оборот данные местных архивов [12; 13]. Каждый регион рассматривается в русле всероссийской истории, но прослеживаются особенные, самобытные черты.

Анализ поведения крестьян Владимирской губернии в марте - октябре 1917 года усложняется отсутствием достоверной обобщающей статистики. Да, сведения о различных происшествиях на местах, дополненные сообщениями из прессы, отправлялись прямиком в МВД, а именно в Главное управление по делам милиции, где они затем сводились в таблицы по неделям, месяцам, а иногда и дням [14, л. 2-137]. Однако эти данные обрывочны, в частности, нет данных для Владимирской губернии за март и апрель. Но самое важное, что при сопоставлении с данными из рапортов уездных комиссаров эти сводки не выдерживают ровно никакой критики. Например, по данным МВД за сентябрь во Владимирской губернии была совершена только одна порубка частновладельческого леса. А по сообщению комиссара, в одном только Гороховецком уезде с 15 сентября по 1 октября их было совершено 7 [15, л. 121], плюс 2 жалобы на порубку леса в Ковровском уезде за последнюю неделю сентября и ряд случаев в других уездах $[15$, л. $108,110,149]$. Такая же ситуация наблюдается в октябре: МВД говорит о 7 земельных правонарушениях, а по донесениям губернскому комиссару - минимум 20 посчитанных случаев в 4 уездах из 13, плюс общие формулировки об идущих массовых самовольных порубках и расхищении леса в других уездах [15, л. 124, 134, 136, 142, 111 об.].

Следовательно, есть все основания считать цифры представленных сводок в отношении Владимирской губернии неполными. Однако формы социального поведения, описанные в них, совпадают с данными в рапортах и прессе. Это позволяет нам судить об общих тенденциях поведенческих реакций сельского населения в марте - октябре 1917 года. 
Так, сведения о земельных правонарушениях во Владимирской губернии в марте - августе 1917 г., обработанные в МВД, демонстрируют преобладание захватов леса (или же лесных порубок), лугов и покосов, а также препятствие рубке и вывозу леса, реже захват имений (табл. 1). Не изменяются эти формы и к осени: в сентябре и октябре 1917 г. из 8 случаев наблюдается 7 лесных порубок и 1 запрет рубки и вывоза леса.

Вышедший в 1927 году сборник документов «Крестьянское движение в 1917 году», также основанный на уже упомянутых сведениях о происшествиях на местах, содержит не только цифры, но и конкретные сюжеты, жалобы и заявления землевладельцев. Однако сами составители делают оговорку на ограниченность этих сведений как со стороны потерпевших - желанием раздуть ситуацию, так и со стороны комиссаров - желанием доказать активную деятельность, а также «чисто механическими» сокращениями секретарей департамента [16, с. XXV-XXVI].

Обобщив эти данные по Владимирской губернии, мы видим чуть дополненные, но схожие цифры:

- в апреле было сообщено о 2 инцидентах: 2 самоуправства в имениях и угрозы вырубки леса;

- май - 5, из них 3 препятствия к вырубке и продаже лесных материалов, 1 препятствие погрузке патоки с завода и 1 опасение в связи с агитацией, призывающей к насилию;

- июнь - 3, из них 1 препятствие разработке леса, 1 массовая порубка и 1 интересный случай освобождения крестьянами и ткацкими рабочими фабриканта Смолякова. Фабрикант до этого был самовольно арестован вооруженными солдатами и рабочими за отказ удовлетворить их требования;

- июль - 7, из них 5 самовольных покоса и захвата лугов (1 из которых по решению земельного комитета), 2 реквизиции молочного скота (1 из которых сопровождался оскорблением и угрозой убийства при возражении);

- август - 10, из них 5 связаны с нехваткой продовольствия (разгром продуправы, препятствие крестьянами-общинниками вывозу хлеба крестьяниномотрубником, снятие хлеба с парохода, обыски в домах с поиском запасов продовольствия), 2 препятствия покосу и порубке, 1 самовольный покос, 1 порубка леса, 1 реквизиция молочного скота;

- сентябрь - 3, из них 1 приостановка вывоза дров с частновладельческой дачи, 1 домашний арест служащих в имении и 1 обыск и арест владельца имения. Все они были санкционированы исполнительными комитетами;
- октябрь -7 , из которых только 1 связан с арестом толпой крестьян управляющего имением. Ocтальные 6 - с массовой порубкой частновладельческого леса, приостановкой работ по его разработке и самовольным вывозом дров (Составлено по: [16, с. $25,64-65,116-117,180-181,236-237,296,346])$.

Сравнивая представленные цифры с данными по другим губерниям (только в июле 1917 года в Московской губернии было 15 земельных правонарушений, в Нижегородской - 10, в Казанской - 75, в Могилёвской -74 , Рязанской -43 , Тверской -23 , а общее число за месяц - 1122 земельных правонарушения) [14, л. 15-17], мы можем назвать их низкими. Но даже они свидетельствуют об увеличении «земельных правонарушений» во Владимирской губернии с относительным затишьем на сентябрьскую страду. Только вот преобладающие формы этого аграрного движения - отнюдь не революционные погромы, не прямые захваты имений или же насилия над помещиками. Прежде всего мы видим нарастающие конфликты с любыми держателями земли (леса) и продовольствия.

Теперь разберемся подробнее, что скрывается за данными сухими сводками. Подобная статистика, являясь довольно «скупой», отражает только крупные события, оставляя за кадром множество будничных реакций.

Весной, по сообщениям уездных комиссаров, больше всего конфликтов возникало по поводу леса: крестьяне обвиняли лесопромышленников в незаконной вырубке лесов, а частные владельцы, наоборот, жаловались, что крестьяне препятствовали разрабатывать лесной массив или начинали самовольные порубки. Впрочем, споры удавалось улаживать, и они не перемещались в плоскость насилия [17, л. 9 , $11-14 ; 15$, л. $19 ; 18$, л. 130].

Несмотря на то, что всеми общественными организациями провозглашалось сохранение права собственности и недопустимость его нарушения [19, л. 115-116], землевладельцы и их интересы защищались слабо. Так, землевладелец Судогодского уезда Н.А. Мокеев 15 июня 1917 г. жалуется на местных крестьян, которые с Фоминой недели, т.е. с 12 апреля, начали производить «своеволия, самоуправство и бесчинства» в его имении. Ни начальник милиции, ни уездный комиссар никаких мер не предприняли, и самоуправства в имении стали рядовым явлением. Показательно, что 24 июня исполком признал действия крестьян правильными, даже расходы по командировке возложил на Мокеева [20, л. 4].

Таблица 1 - Земельные правонарушения во Владимирской губернии в мае - октябре 1917 г.

\begin{tabular}{|c|c|c|c|c|c|c|c|c|}
\hline \multirow[b]{2}{*}{ Месяц } & \multicolumn{5}{|c|}{ Захваты } & \multirow{2}{*}{$\begin{array}{c}\text { Препятствие } \\
\text { рубке } \\
\text { и вывозу леса }\end{array}$} & \multirow{2}{*}{$\begin{array}{c}\text { Осталь- } \\
\text { ные }\end{array}$} & \multirow[b]{2}{*}{ Итого } \\
\hline & имений & $\begin{array}{c}\text { лугов } \\
\text { и покосов } \\
\end{array}$ & $\begin{array}{c}\text { леса } \\
\text { (лесные порубки) }\end{array}$ & инвентаря & урожая & & & \\
\hline Май & & & 1 & & & 1 & 1 & 3 \\
\hline Июнь & 2 & & 1 & & & 2 & & 5 \\
\hline Июль & 1 & 3 & 1 & 1 & & & 3 & 9 \\
\hline Август & & 2 & & 1 & 2 & & & 5 \\
\hline Сентябрь & & & 1 & & & & & 1 \\
\hline Октябрь & & & 6 & & & 1 & & 7 \\
\hline
\end{tabular}

Примечание. Составлено по: [14, л. 2-137]. 
Птицына Г.М.

Конфликты крестьян в марте-октябре 1917 г. (на материалах Владимирской губернии) Исторические науки и археология

Что же собой представляли эти своеволия? Мокеев расписывает их подробно:

«- изломали загородь моей усадьбы, отрывая с гвоздями целыми звеньями;

- разрывали на моей усадьбе родник и превратили его в колодец, для прохода к нему выпилили часть изгороди;

- открыто пасут скот на моих лугах и по молодым лесным зарослям;

- травят и портят как луга, так и заросли;

- разваливали на усадьбе поленницы дров и били кирпичи;

- уничтожают скотом канавы;

- открыто рубят и похищают мой лес на глазах местных милиционеров и даже при содействии их».

«Вытравив у меня все луга, теперь крестьяне намерены скосить и остатки, и даже захватывают для скоса мой сад! - пишет землевладелец. - Устраняют моего сторожа от охраны, угрожают ему насилием и даже намерены захватить и скосить данный ему, как сторожу, небольшой участок луга» [20, л. 4].

Для исполкомов интересы целых сельских обществ превалировали над интересами отдельно взятых землевладельцев. Поэтому исполнительный комитет, разбиравший это дело, мало того, что признал действия крестьян правильными, так ещё и расходы по командировке возложил на Мокеева [20, л. 6, 7]

Многие землевладельцы находились в других городах, что крестьянам было только на руку. 14 марта, вскоре после свержения самодержавия, московский дворянин Костенский посылает прошение в Исполком следующего содержания: «До моего сведения дошло, что общество крестьян с. Румянцева Суздальского уезда собирает сходы и обсуждает, следует ли им рубить мой лес. Прошу разъяснить крестьянам и уведомить меня» [19, л. 115]. 4 апреля Суздальский исполком ответил Костенскому, что никаких самоуправных действий по отношению к его собственности не предпринималось и предприниматься не будет. Однако попросили сообщить, будет ли он запахивать землю. Если да, то он должен приступить к работе с 20 апреля с/г, а если не приступит, то его земля будет запахана (для продажи, населения и армии) [19, л. 108].

Пишет из г. Судогды крестьянин д. Тимофеевская Судогодского уезда С.М. Петров, что его бывший работник, беженец Герасимчук со своей семьей самовольно проживает в имении Петрова. Непрошеный гость пользуется его имуществом и запасенными овощами, а также захватил и смолол в муку 10 мер семенной ржи, предназначенной для посева на 1918 год, поэтому часть земли осталась незасеянной. Самоволец запрещал жить в этом имении наемным рабочим, из-за чего трое отказались от работ. Более того, общество крестьян деревни Федоровки, на основании постановления волостного комитета, пасет скот по посевным лугам и озимому хлебу в имении. Сам Петров проживал в г. Судогда в собственном доме и просил оградить его имущество от захвата и произвола [21, л. 1].

Описанное поведение Я.А. Яковлев в предисловии к сборнику документов «Крестьянское движение в 1917 году», вышедшему в 1927 году, назовет «способами мирной борьбы с помещиками», «дезорганизацией помещичьего хозяйства» [16, с. III-IV]. При этом крестьяне в марте-октябре 1917 г. действуют 186 коллективно, предварительно принимая решения на сельских сходах и санкционируя их постановлениями революционной власти, например исполкомов или земельных комитетов.

Впрочем, конфликты, как столкновения интересов, у крестьян Владимирской губернии проходили не только с помещиками, а сразу на нескольких осях.

Во-первых, важным стал конфликт на оси «город - деревня», где в понятие «город» мы включаем не только жителей городов, но и заводчиков, использующих в качестве сырья продукты крестьянского труда. О вражде между рабочими и жителями деревень из-за повышения цен на сельскохозяйственные продукты писал в сентябре Меленковский уездный комиссар [15, л. 112]. О пренебрежительном отношении крестьян к рабочим, в связи с установлением 8ми часового рабочего дня и дефицита промышленных товаров, писала пресса: «Крестьяне-де работают 24 часа в сутки, а рабочие - на ко се - только 8 часов!» [22].

В силу своей неграмотности, крестьяне не понимали рыночных механизмов, поэтому считали, например, справедливым выставлять заоблачные цены и менять условия сделки купли-продажи даже после ее совершения. При этом, почувствовав безнаказанность и лояльность исполкомов, начинают действовать увереннее, а в некоторых случаях и угрожать насилием.

Так, еще в мае заводчики по картофельнотёрочному производству Меленковского и Муромского уездов обратились к губернскому комиссару с жалобой на крестьян, которые поставляют им картофель. Последние уже после фактической продажи картофеля увеличили цену с 4 руб. 40 коп. до 7 руб. 80 коп. Затем крестьяне обратились в Меленковский исполком, который санкционировал их требования и призвал заводчиков заплатить. Когда же заводчики отказались это сделать, крестьяне стали угрожать насилием. «Положение настолько обострилось, что мы были вынуждены выехать из мест своего жительства, оставив имущество и семьи на произвол судьбы», - пишут напуганные заводчики [23, л. 21].

Другой случай произошел уже в первых числах сентября. Гороховецкая городская управа закупила в селениях Усадской волости более 20000 пудов картофеля для населения Гороховца по цене 16 руб. четверть. Когда деньги уже были отданы, а картофель погружен на баржу, торговцы потребовали доплаты за каждую четверть по 3 руб. 20 коп. Губернский комиссар попросил уездного объяснить крестьянам, что всё купленное после совершенной сделки принадлежит покупателю и все требования о доплате рассматриваются как спекуляция, караемая привлечением к уголовной ответственности [21, л. 30-33].

Вторая ось - «община - частные землевладельцы», причем под последними понимаются не только помещики, но и хуторяне, а также отрубники, которые испытывали на себе особую агрессию со стороны общины. Например, крестьяне деревень Кочуково, Курилово и Анисимово потребовали от хуторян из Минской губернии прекратить пользоваться землей. Губернский исполком командировал туда членов комитета для разъяснения крестьянам незаконности таких выступлений [24].

Тяжело приходилось крестьянину одному, вне общины. Его частная собственность или арендован- 
ные земли были под постоянной угрозой со стороны сельских обществ. Слабость и бесполезность милиции делала Советы и исполкомы последней надеждой на защиту. Так, 10 июня просит у Совета справедливости крестьянин Боголюбовской волости Владимирского уезда Василий Спиридонович Горбеев. Завод трех братьев Горбеевых был основан около 100 лет назад на 9 десятинах земли, которую купил их отец, заплатив за нее 120000 штук кирпича. Сами братья после смерти отца владели землей уже 35 лет. К 1917 году на кирпичном заводе Василий работал один, без наемных рабочих. 9 июня на завод явились крестьяне с. Добрынское Боголюбовской волости с требованием, чтобы Горбеев к 12 июня прекратил работу и уехал, в противном случае они придут и раскидают все. «При Новом или Старом Правительстве, - пишет Горбеев, - я тут собственноручно зарабатывал себе и своему семейству хлеб, но у меня безо всякого суда и объяснений хотят все отнять». Указывает Василий и причину происходящего - агитация среди крестьян солдата Василия Антонова, прибывшего на побывку в с. Добрынское. Солдат заявлял, что «все суды кончились» и теперь по постановлениям сельского схода можно взять что угодно. Антонов призывал рубить лес, вывозить дрова, а также не платить оброк. Поэтому крестьяне, которые уже заплатили оброк, поддавшись солдатской пропаганде, шли к сборщику с требованием вернуть деньги обратно [25, л. 68].

Крестьянин д. Злобино, «гражданин-собственник» огороженного участка с мельницей и другими постройками, 6 октября бьет тревогу. Сельский комитет постановил самовольно сломать его забор и постройки, его самого лишить права собственности, а землю отдать другим людям [23, л. 131].

Не делала поблажек община и для жен солдат, находившихся на службе. Например, солдатка Е.А. Филатова из с. Непотягова Суздальского уезда 17 мая отправляет прошение: «У меня имеется 13 десятин земли, приобретенной моим мужем от крестьянского поземельного банка. Засеяна она 4,5 - клевером, 4,5 - ржи (2 яровой, 2 под паром). Непотяговское общество постановило отобрать у меня паровую землю и запретило мне возить навоз. Я в будущем должна остаться без хлеба. Законно ли это?». Исполком 16 июня признал недопустимым изъятие земли у Филатовой [19, л. 56, 58 об.].

Заступается за свою жену перед советом солдатских депутатов рядовой 82 запасного полка Михаил Якимович Сотский. 7 июня он пишет, что несколько лет арендовал луговую землю у соседнего помещика Лаптева. В это же лето крестьяне д. Надеждина сняли у Лаптева луга в общественную аренду и отняли участок земли Сотского. Жена Михаила Якимовича, оставшаяся одна дома с малыми детьми без денег и земли, вынуждена теперь продать корову, которая служила для нее единственным источником пропитания. Совет оказал содействие, и волостной земельный комитет 26 июня решил проблему в пользу Сотского [25, л. 109-110].

Дополняя статистику о запрете разработки леса, стоит сказать, что крестьяне не допускали и вывоз леса, предназначенного для нужд государственной обороны. Например, в начале лета граждане д. Березники Гороховецкого уезда препятствовали вывозу бревен и шпал на железнодорожную станцию для их отправки на Нижегородский завод взрывчатых веществ [25, л. 67]. Крестьяне д. Икшева запрещали Московско-Казанской железной дороге разрабатывать 62 десятины купленного у казны леса [26, л. 7].

Существовали конфликты и на оси «община община». Действуя в своих интересах, сельское общество не учитывало претензии своих соседей. Ни о какой солидарности речи быть не могло, особенно когда дело касалось использования земли. Поэтому с мая по октябрь поступают крестьянские жалобы на соседние деревни, которые самовольно косят траву, пасут скот по молодому лесу и лугам, подлежащим покосу, рубят лес, а также не дают продавать жителям соседних деревень сучки и дрова [19, л. $112 ; 25$, л. 55; 15, л. 134]. Например, крестьяне деревни Усад самовольно косили луга, предоставленные Меленковской земельной управой крестьянам деревни Малютинки и Косиковки. Чтобы прекратить это, 29 июля уездный исполком направил туда воинскую команду. В итоге пришли к соглашению, что крестьяне деревни Усад заплатят 330 руб. потерпевшим селениям за отказ от переданных им лугов [26, л. 6 об.].

Сталкиваются лоб в лоб «законные» решения крестьянских сходов. Так, Короваевский сельский сход Юрьевского уезда летом просил губернский исполком пересмотреть постановления Коварчинского волостного комитета. Последний «самовольно» принял во владение луга «Еремеево» Е.И. Моторкиной и разделил их между гражданами Суздальского уезда «Луг находится в 1/8 версты от нашего селения и был уже нами заарендован, - объясняют короваевцы. - Назначен же этот луг теперь д. Авксеньево, расположенной от него в 3-х верстах и ранее почти не арендовавшей его. Мы арендовали его в силу крайней необходимости! Скот наш стоял бы во дворах или же ходил всё лето по голому полю, т.к. половина нашего надела, как пахотного, так и лугового, находится от нас в 5 верстах с 4 чужими наделами. Больше арендовать негде». Губернский исполком признал действия Коварчинского волостного комитета правильными [20, л. 16].

К четвертой группе относятся конфликты, замыкающиеся внутри самой общины. Они продолжали решаться на деревенских сходах по законам обычного права, поэтому информация по таким делам редко выходила за пределы общины, за исключением жалоб самих пострадавших или вызывающих случаев арестов и самосудов. Подобные сюжеты в изучаемом регионе касались споров из-за арендованных земель [25, л. 116], а также поджигателей [27, л. 296; 15, л. 148].

Важно отметить, что по Владимирской губернии мы не находим жалоб или прошений от зажиточных крестьян-общинников. К парадоксальному выводу приходит социолог-крестьяновед Т. Шанин. Он отмечал, что, несмотря на расслоение крестьянства, в российской деревне не было классовой розни. Причина тому - явление, которое автор называет циклической мобильностью: в общине одновременно шли процессы социально-экономического расслоения и выравнивания хозяйств (когда глава семейства делит всё нажитое своим трудом между сыновьями) [28, c. $38-40]$.

Конфликты с властью возникали на первых поpax, как обыски и аресты ненавистной царской администрации [29, л. 8; 26, л. 5-5 об.; 25, л. 64]. Особую нелюбовь в марте испытали на себе сельские и 
волостные старшины, а также председатели волостных попечительств. Их обвиняли в злоупотреблениях при выдаче продуктов крестьянам, а также пайков семьям призванных на войну [30-32]. Затем открытые столкновения возникали в том случае, если государство оказывалось собственником приглянувшейся крестьянам земли, а также когда революционная власть пыталась помешать крестьянам претворять в жизнь свои «законные» постановления. У милиции не было законодательных инструментов воздействия на крестьян, кроме словесных методов и составления протокола, поэтому к октябрю с милиционерами и комиссарами уже открыто не считались $[15$, л. 142 ; 23, л. 167 об.].

Также на линии огня оказались продовольственные управы, которые непросвещенное сельское население считало главным виновником голода: якобы эти органы спекулируют и специально утаивают хлеб. Поэтому с сентября крестьяне начинают «осаждать» продовольственные управы с требованием выдачи хлеба [21, л. 59, 62].

Таким образом, тезис советской историографии о том, что основными врагами крестьян были помещики, кулаки и «буржуазное» Временное правительство, не находит документального подтверждения. Община в марте - октябре 1917 г., выступая единым организмом, оказалась против всего социального окружения. Её конфликты проходили сразу на нескольких осях: «город - деревня», «община - частные владельцы», «община - община» и внутриобщинные споры. Возникали также конфликты с государством, но они были отнюдь не политическими. Источники свидетельствуют, что революционное насилие и разгром имений не были широко распространены по Владимирской губернии в указанный период, не видим мы и политических лозунгов - конечной целью крестьян было решение вопросов продовольствия, а также использования земли и леса. При этом для крестьян не имело значения, кто собственник нужного им ресурса - помещик, крестьянин, государство или общественная организация.

Октябрьское вооруженное восстание в столице не повлияло на формы социального поведения крестьян Владимирской губернии. Но оставшись прежними, в силу безнаказанности, они приобрели наиболее резкие черты - чаще сопровождались насилием и захватом имущества.

\section{Список литературы:}

1. Марченя П.П. Крестьянское сознание как доминанта Русской революции // Научный диалог. 2015. № 12 (48). С. 303-315.

2. Пушкарева Н.Л., Любичанковский С.В. Понимание истории повседневности в современном историческом исследовании: от школы Анналов к российской философской школе // Вестник ЛГУ им. А.С. Пушкина. 2014. № 1. С. 7-21.

3. Малявский А.Д. Крестьянское движение в России в 1917 г., март - октябрь. М.: Наука, 1981. 400 с.

4. Кравчук Н.А. Массовое крестьянское движение в России накануне октября: (март - октябрь 1917 г. по материалам великорусских губерний Европейской России). М.: Мысль, 1971. 278 с.

5. Осипова Т.В. Классовая борьба в деревне в период подготовки и проведения Великой Октябрьской социалистической революции. М.: Наука, 1974. 350 с.
6. Тютюкин С.В. Война, мир, революция. Идейная борьба в рабочем движении России 1914-1917 гг. М.: Мысль, 1972. 304 с.

7. Бухарев В.М., Люкшин Д.И. Российская смута начала XX века как общинная революция // Историческая наука в меняющемся мире. Вып. 2. Историография отечественной истории. Казань: Изд-во Казан. ун-та, 1994. С. 154-160.

8. Дьячков В.Л., Есиков С.А., Канищев В.В., Протасов Л.Г. Крестьяне и власть (опыт регионального изучения) // Менталитет и аграрное развитие России (XIX-XX вв.): мат-лы междунар. конф. (14-15 июня 1994 г.). М.: РОССПЭН, 1996. С. 146-154.

9. Вронский О.Г. Государственная власть России и крестьянская община в годы «великих потрясений» (1905-1917). М.: МГПУ, 2000. 418 с.

10. Булдаков В.П. Имперство и российская революционность (Критические заметки) // Отечественная история. 1997. № 1. С. 42-60.

11. Поршнева О.С. Менталитет и социальное поведение рабочих, крестьян и солдат России в период Первой мировой войны, 1914-1918 гг.: дис. ... д-ра ист. наук. Екатеринбург, 2000. 359 с.

12. Кижаева Т.А. Менталитет и социальное поведение сельского населения Томской губернии в годы Первой мировой войны: 1914-1917 гг.: дис. ... канд. ист. наук. Барнаул, 2006. 207 с.

13. Журавлева М.Д. Крестьянство Среднего Поволжья в годы первой мировой войны: Общественное сознание и социальное поведение: дис. ... канд. ист. наук. Саранск, 2001. 239 с.

14. Государственный архив Российской Федерации (ГАРФ). Ф. 1791. Оп. 6. Д. 337.

15. Государственный архив Владимирской области (ГАВО). Ф. 1186. Оп. 2. Д. 42.

16. Крестьянское движение в 1917 году / Центр. архив; подг. к печати К.Г. Котельников и В.Л. Меллер; с предисловием Я.А. Яковлева. М.; Л., 1927. $442 \mathrm{c}$.

17. ГАВО. Ф. 1186. Оп. 1. Д. 62.

18. ГАВО. Ф. Р-26. Оп. 1. Д. 130.

19. ГАВО. Ф. 1181. Оп. 1. Д. 120

20. ГАВО. Ф. 1181. Оп. 1. Д. 94.

21. ГАВО. Ф. 1186. Оп. 2. Д. 65.

22. Леонтьев П. Голод, рабочие и крестьяне // Владимирская жизнь. 1917. № 27 (14 октября). С. 2.

23. ГАВО. Ф. 1190. Оп. 1. Д. 15.

24. Деятельность, постановления и распоряжения Владимирского исполнительного комитета // Известия Владимирского губернского Временного исполнительного комитета. 1917. № 11 (16 марта). С. 1.

25. ГАВО. Ф. Р-26. Оп. 1. Д. 4.

26. ГАВО. Ф. 1190. Оп. 1. Д. 10.

27. ГАВО. Ф. 1186. Оп. 1. Д. 56.

28. Шанин Т. Социально-экономическая мобильность и история сельской России 1905-1930 гг. // Социологические исследования. 2002. № 1. С. 30-40.

29. ГАРФ. Ф. 1788. Оп. 2. Д. 159.

30. От наших корреспондентов. С. Аргуново, Покровского уезда // Старый Владимирец. 1917. № 47 (1 марта). С. 3.

31. Бабий конвой // Старый Владимирец. 1917. № 54 (9 марта). С. 3.

32. Новые аресты // Старый Владимирец. 1917. № 56 (11 марта). С. 3. 


\title{
CONFLICTS OF PEASANTS IN MARCH-OCTOBER 1917 (BASED ON MATERIALS FROM THE VLADIMIR PROVINCE)
}

(C) 2020

\author{
Ptitsyna Galina Mikhailovna, assistant of Russian History Department \\ Vladimir State University (Vladimir, Russian Federation)
}

\begin{abstract}
This paper presents an analysis of the social behavior of peasants in the Vladimir province in MarchOctober 1917 for their conflicts and highlights the main directions of confrontation. The characteristic of the elaboration of the problem by both Soviet and modern historical science is given. The limited use of statistics on the selected region is explained and the methodological basis of the study is determined. The author considers the conflicts of peasants not only from the side of statistics, but also from the standpoint of individual plots that better reveal everyday behavioral practices. The work describes in detail and group the clash of interests of peasants with the surrounding social reality. The conclusion is drawn about the baselessness of the thesis of the Soviet historiography that the main enemies for peasants were landlords, kulaks and the bourgeois' Provisional Government. The analysis of sources revealed that the peasant commune in March-October 1917, solving its pressing issues of food and land-use, was against all. Its conflicts took place on several directions at once: «city - village», «commune - private owners», «commune - commune» and intra-commune disputes. There were also conflicts with the state, but they were not political.

Keywords: Russian peasantry; Russian revolution of 1917; Vladimir Gubernia; Provisional Government; peasant commune; commune revolution; peasant movement; social behavior; conflicts; provincial society; revolutionary power; historical anthropology; history of everyday life.
\end{abstract}

\section{ИСТОРИЯ НАРОДНЫХ СТРОЕК 1940 ГОДА (НА ПРИМЕРЕ ФЕРГАНСКОЙ ДОЛИНЫ)} (C) 2020

\author{
Насритдинов Кабулжан Махамаджанович, кандидат исторических наук, \\ доцент кафедры гуманитарных наук \\ Андижанский филиал Ташкентского государственного аграрного университета \\ (2. Андижан, Республика Узбекистан)
}

\begin{abstract}
Аннотация. На основе научно-исторических и архивных источников автор статьи анализирует историю выработки планов по орошению целинных земель центральной части Ферганской долины в первой половине XX века крупными русскими учеными, специалистами и показывает историческую картину строительства ирригационных сооружений в Ферганской долине в 1940 году скоростным народным методом «хашар». Со строительством гидротехнических сооружений, таких как Северный и Южный Ферганские каналы, начался новый этап в развитии орошаемого земледелия Ферганской долины, так как воды этих гидротехнических сооружений дали возможность оросить новые целинные земли центральной части и предгорных районов Ферганской долины. Следует отметить, что эти крупные и по своей конструкции сложные оросительные каналы были построены в основном с помощью примитивных орудий труда, таких как кетмень, лом, лопата, носилки, кирки и мешки, благодаря трудовому подвигу народов Узбекистана. Эти гидротехнические сооружения вот уже почти 80 лет обеспечивают сельскохозяйственные районы живительной влагой. Также в статье автор обобщает суть экономических мероприятий, осуществленных Советским правительством по развитию орошаемого земледелия в долине.
\end{abstract}

Ключевые слова: Ферганская долина; земледелие; орошение; русло; акведук; сифон; экстенсивный путь развития; мешок; хашар; кетмень; лопата; лом; кубометр; ирригация; гидротехническое сооружение; мелиорация; предгорный район; канал; гидроузел; строительство; район; правительство; народная стройка; дамба; плотина; проект; хребет; водосброс; гектар; колхоз.

Из исторических источников нам известно, что 1932 году в Советском Союзе была достигнута «хлопковая независимость», так как в хлопкосеющих союзных республиках в 1932 году было выращено 1216617 т хлопка. Доля хлопка, выращенного в Республике Узбекистан, составляла более 758044 т, а в процентном соотношении она равнялась $65 \%$ общего урожая [1, с. 166].

Учитывая это обстоятельство, союзное правительство приняло решение к изысканию возможностей Узбекской Республики в дальнейшем развитии хлопководства. По этому решению правительством была поставлена задача выработать генеральный рабочий план по орошению новых земель Ферганской долины, так как в 30-е годы XX века Ферганская долина была основным хлопкосеющим регионом Республики Узбекистан.

После принятия этого решения на территории всей долины велись комплексные проектно-изыскательские и научно-практические работы по изучению природных возможностей дальнейшего развития хлопководства. В этих комплексных работах, по 